\title{
STUDIES ON SOME FOOD POISONING BACTERIA IN RAW MILK SOLD IN SHARKIA GOVERNORATE
}

\author{
ABD-EL-KALIEK, A.A.; MASOUD, S.E. and MONA, T.A. RASLAN \\ Animal Health Research Institute Zagazig Provincial Laboratory
}

\begin{tabular}{|c|c|}
\hline & ABSTRACT \\
\hline Accepted: $12 / 6 / 2013$ & $\begin{array}{l}\text { One hundred raw farm bulk milk samples were collected from Sharkia } \\
\text { Governorate. A survey was conducted to determine the incidence of food } \\
\text { poisoning bacteria in raw milk and experiments were carried to determine } \\
\text { antibiotic sensitivity of Campylobacter jejuni \& Yersinia enterocolitica and } \\
\text { proteolytic \& lipolytic activities of isolated Pseudomonas spp. Out of the } 100 \\
\text { raw farm bulk milk samples tested } 1(1 \%), 1(1 \%) \text { and } 2(2.0 \%) \text { were found to } \\
\text { contain, Campylobacter jejuni against Karmali, Columbia and modified } \\
\text { Preston agar, respectively. Serotyping of Campylobacter jejuni isolated from } \\
\text { the examined raw milk samples resulted in two strains were belonged to } \\
\text { Campylobacter jejuni serotype } 2 \text { while only one was Campylobacter jejuni } \\
\text { serotype } 1 \text {. Antibiotic sensitivity revealed that all the tested Campylobacter } \\
\text { jejuni isolates were } 100 \% \text { sensitive to Genitamycin and Chloramphenicol } \\
\text { while none were sensitive to Cefoperazone and Ampicillin. Yersinia } \\
\text { enterocolitica and Yersinia krestensenii could be detected in } 7 \% \text { and } 4 \% \\
\text { respectively when cultured on bile oxalate sorbose enrichment broth, while } \\
\text { using Yersinia enrichment broth (YEB) } 7.33 \% \text { and } 4 \% \text { of milk samples were } \\
\text { positive for Yersinia enterocolitica and Yersinia krestensenii respectively. } \\
50 \% \text { of the examined samples were contaminated with Pseudomonas spp. } \\
\text { The high level of contamination was } 0.5 \times 10^{8} \text {; the low level was } 2.3 \times 10^{2} \\
\text { and the mean value was } 1.8 \times 10^{4} \pm 0.5 \times 10^{4} \text {. Also, it is found that out of the } \\
\text { examined } 100 \text { raw bulk milk samples } 2(2 \%) \text { were positive for E. coli. }\end{array}$ \\
\hline
\end{tabular}

Key words: Food Poisoning, Raw milk, Antibiotics

\section{INTRODUCTION}

Food-borne illness was principally associated with five well-recognized pathogens. These include: Staphylococcus aureus, Salmonella spp., Clostridium botulinum, Clostridium perfringens and Bacillus cereus. However, each year the etiological agents responsible for food-borne diseases were not identified for more than $50 \%$ of outbreaks. Many reasons may explain this frequent inability to identify organisms, including the fact that many outbreaks were caused by previously unrecognized pathogens or by known pathogens not previously recognized as agents of food-borne illness. Within the past 10 to 15 years, several other pathogens had been identified as important causes of food-borne diseases including Campylobacter jejuni, Yersinia enterocolitica and E. coli 0157:H7 (Doyle, 1992).

Milk and milk products have frequently implicated in the transmission of human pathogens, including Salmonella spp., Campylobacter jejuni and Yersinia enterocolitica. Because proper pasteurization kills these pathogens, most milk-borne outbreaks of human illness have been associated with raw or inadequately pasteurized milk or with milk contaminated after pasteurization (Bryan, 1983).

More than a decade ago; Campylobacter jejuni was considered as a pathogen primarily of veterinarian significance. Within the last decade, Campylobacter jejuni had been recognized as gastroenteritis Pathogen.

Yersinia enterocolitica has been isolated from many animal species, with most isolates being a virulent for humans. Exception is swine, they are the principal reservoir for virulent strains, which are often isolated from oral cavity (tongue and tonsils) of apparently healthy animals. Outbreaks caused by agents have included chocolate and pasteurized milk (Anonymous, 1977 and Tacket et al., 1984) More recently, E. coli serotype O157:H7 has recently emerged as a significant food-borne pathogen, causing hemorrhagic colitis in human and hemorrhagic uremic syndrome (Eley, 1996).

Therefore the present study was undertaken to investigate the incelence of prevalence of Campylobacter jejuni; Yersenia spp.; Pseudomonas 
spp. and E. coli in raw milk sold in Sharkia Governorate.

\section{MATERIALS and METHODS}

\section{Sampling:}

One hundred random raw milk samples were collected from different dairy farms in Sharkia Governorate.

$500 \mathrm{ml}$ of milk proved to be raw by storch test (FDA 1998) were collected in a sterile capped bottle. All samples were placed into an insulated ice-box and transferred to the laboratory within one hour of sampling. The samples were held in refrigerator $(4-$ $7^{\circ} \mathrm{C}$ ) until examination within 12 hours.

\section{1 - Isolation and identification of Campylobacter jejuni according to (FDA 1998): \\ Pre-enrichment:}

The $\mathrm{pH}$ value of the raw milk was adjusted using $\mathrm{pH}$ test paper ( $\mathrm{pH}$ 6-8 range) if the $\mathrm{pH}$ is below 7.6, sterile 1-2 $\mathrm{N} \mathrm{NaOH}$ was added and gently adjust to $7.5 \pm 0.2$.

$50 \mathrm{ml}$ milk were centrifuged at 20000-x g for 40 minutes. Supernatant was discarded and pellet (not fat layer) was dissolved in $10 \mathrm{ml}$ enrichment broth (Bolton broth) supplemented with vial each of FBP and Bolton broth selective supplement.

The pellet was transferred to $90 \mathrm{ml}$ enrichment broth in screw-capped bottle. The enrichment broth was incubated at $42^{\circ} \mathrm{C}$ for $48 \mathrm{hrs}$.

\section{Plating on selective media:}

After appropriate enrichment, loopfuls from each liquid culture were streaked onto the following media:

(1) Columbia agar base, supplemented with BlaserWang supplement and 5-7\% laked horse blood (Hundson et al., 1999).

(2) Campylobacter agar base (Karmali) supplemented with campylobacter selective supplement (Lovett et al., 1983).

(3) Campylobacter blood-free selective medium (modified CCDA-Preston) supplemented with CCDA selective supplement (Federighi et al., 1999).

Inoculated plates were incubated at $42^{\circ} \mathrm{C} / 48 \mathrm{hrs}$ in case of Columbia agar base and Karmalli, and at $37^{\circ} \mathrm{C} / 48$ hrs for modified CCDA Preston, microaerobically (in an atmosphere consists of approximately 5-6\% Oxygen, 10\% Carbon dioxide and $84-85 \%$ Nitrogen). This is achieved by using campygen $\mathrm{CN} 25$ in conjugation with 2.5-liter capacity anaerobic jar.

Antibiotic sensitivity of campylobacter from examined raw milk samples according to Wells et al. (1987).

2- Isolation and Identification of Yersinia in milk according Thisted and Danielsson (2005).

3- Isolation and identification Psudomonaus, according to Peters et al. (2006).

4- Isolation and identification $E$. coli according to Crochshang 1975.

\section{RESULTS}

Table 1: Prevalence of Campylobacter jejuni in the examined raw farm bulk milk samples

\begin{tabular}{|c|c|c|c|c|c|c|}
\hline $\begin{array}{c}\text { No. of } \\
\text { samples }\end{array}$ & \multicolumn{6}{|c|}{ Types of media } \\
\hline \multirow{4}{*}{100} & \multicolumn{2}{|c|}{ Karmali } & \multicolumn{2}{|c|}{ Columbia agar base } & \multicolumn{2}{|c|}{$\begin{array}{l}\text { Modified Preston } \\
\text { (CCDA) }\end{array}$} \\
\hline & \multicolumn{2}{|c|}{ Positive samples } & \multicolumn{2}{|c|}{ Positive samples } & \multicolumn{2}{|c|}{ Positive samples } \\
\hline & No. & $\%$ & No. & $\%$ & No. & $\%$ \\
\hline & 1 & 1 & 1 & 1 & 2 & 2 \\
\hline
\end{tabular}

Table 2: Serotyping of isolated Campylobacter jejuni from the examined raw farm bulk milk samples

\begin{tabular}{|c|c|c|c|c|c|c|}
\hline \multirow{3}{*}{ Serotypes } & \multicolumn{6}{|c|}{ Types of media } \\
\hline & \multicolumn{2}{|c|}{ Karmali } & \multicolumn{2}{|c|}{ Columbia agar base } & \multicolumn{2}{|c|}{ Modified Preston (CCDA) } \\
\hline & No. & $\%$ & No. & $\%$ & No. & $\%$ \\
\hline $\mathrm{Cj}^{2 *}$ & 1 & 1 & 1 & 1 & 1 & 1 \\
\hline Cj1** & - & - & - & & 1 & 1 \\
\hline Total & 1 & 1 & 1 & 1 & 2 & 2 \\
\hline
\end{tabular}


$\underline{\text { Assiut Vet. Med. J. Vol. } 59 \text { No. } 138 \text { July } 2013}$

Table 3: Antibiotic sensitivity of Campylobacter jejuni isolated from examined raw farm bulk milk samples

\begin{tabular}{lcccccccc}
\hline \multirow{2}{*}{ Types of Antibiotics } & \multicolumn{9}{c}{ Campylobacter jejuni isolates } & \multirow{2}{*}{$\begin{array}{c}\text { of } \\
\text { sensitivity }\end{array}$} \\
\cline { 2 - 7 } Gentamycin 10 ugm & CJ2 & CJ2 & CJ2 & CJ2 & CJ2 & CJ1 & CJ1 & ( \\
\hline Tetracycline10 ugm & $\mathrm{S}$ & $\mathrm{S}$ & $\mathrm{S}$ & $\mathrm{S}$ & $\mathrm{S}$ & $\mathrm{S}^{+}$ & $\mathrm{S}^{+}$ & 100 \\
\hline Erythromycin 10 ugm & $\mathrm{S}$ & $\mathrm{S}$ & $\mathrm{S}$ & $\mathrm{MS}$ & $\mathrm{S}$ & $\mathrm{MS}$ & $\mathrm{MS}$ & 100 \\
\hline Cefoperazone 30 ugm & $\mathrm{R}$ & $\mathrm{R}$ & $\mathrm{R}$ & $\mathrm{R}$ & $\mathrm{R}$ & $\mathrm{R}$ & $\mathrm{MS}$ & 14.29 \\
\hline Clindamycin 2 ugm & $\mathrm{R}$ & $\mathrm{R}$ & $\mathrm{R}$ & $\mathrm{R}$ & $\mathrm{R}$ & $\mathrm{R}$ & $\mathrm{R}$ & 0 \\
\hline Ampicillin 10 ugm & $\mathrm{S}$ & $\mathrm{S}$ & $\mathrm{S}$ & $\mathrm{S}$ & $\mathrm{S}$ & $\mathrm{MS}$ & $\mathrm{MS}$ & 100 \\
\hline Nalidixic acid 30 ugm & $\mathrm{R}^{+}$ & $\mathrm{R}^{+}$ & $\mathrm{R}$ & $\mathrm{R}$ & $\mathrm{R}^{+}$ & $\mathrm{R}$ & $\mathrm{R}$ & 0 \\
\hline Chloramphenicol 30 ugm & $\mathrm{S}$ & $\mathrm{S}$ & $\mathrm{S}$ & $\mathrm{S}$ & $\mathrm{S}$ & $\mathrm{S}$ & $\mathrm{S}$ & 100 \\
\hline
\end{tabular}

Table 4: Prevalence of Yersinia spp. in examined raw farm bulk milk samples

\begin{tabular}{ccccccccc}
\hline \multirow{2}{*}{ Total No. } & \multicolumn{3}{c}{ Yersinia enterocolitica } & \multicolumn{3}{c}{ Yersinia kristensenii } \\
\cline { 2 - 8 } & \multicolumn{2}{c}{ BOS } & \multicolumn{2}{c}{ YEB } & \multicolumn{2}{c}{ BOS } & YEB \\
\hline \multirow{3}{*}{100} & Positive sample & Positive sample & Positive sample & Positive sample \\
\cline { 2 - 9 } & No. & $\%$ & No. & $\%$ & No. & $\%$ & No. & $\%$ \\
\cline { 2 - 8 } & 7 & 7 & 6 & 6 & 5 & 5 & 4 & 4 \\
\hline
\end{tabular}

Table 5: Statical analytical results of Pseudomonas spp. in examined raw milk.

\begin{tabular}{ccccccc}
\hline \multirow{2}{*}{ No samples } & \multicolumn{2}{c}{ Positive samples } & Minimum & Maximum & Mean & \pm SEM \\
\cline { 2 - 5 } & No & $\%$ & & & \\
\hline 100 & 50 & 50 & $2.3 \times 10^{2}$ & $5 \times 10^{6}$ & $1.8 \times 10^{4}$ & $0.54 \times 10^{4}$ \\
\hline
\end{tabular}

Table 6: Frequency distribution of Pseudomonas spp. isolated from the examined raw farm bulk milk samples

\begin{tabular}{|c|c|c|}
\hline Pseudomonas strains & $\begin{array}{l}\text { No. of positive } \\
\text { Samples }\end{array}$ & $\begin{array}{c}\% \text { of isolates in relation to No. of } \\
\text { positive samples }\end{array}$ \\
\hline Pseudomonas aeruginosa & 20 & 16.6 \\
\hline Pseudomonas cepacia & 17 & 14 \\
\hline Pseudomonas fluorescens & 50 & 50 \\
\hline Pseudomonas maltophilia & 20 & 16.6 \\
\hline Pseudomonas pickitti & 13 & 10.8 \\
\hline Total & 120 & 100 \\
\hline
\end{tabular}

Table 7: Prevalence of E. coli O157: H7 in the examined raw farm bulk milk samples

\begin{tabular}{ccc}
\hline No of samples & \multicolumn{2}{c}{ E. coli O157: H7 } \\
\hline \multirow{2}{*}{100} & No. of positive samples & $\%$ \\
\cline { 2 - 3 } & 2 & 2 \\
\hline
\end{tabular}




\section{DISCUSSION}

The results given in Table 1 show that out of examined 100 raw farm milk samples, $1(1 \%) 1(1 \%)$ and $2(2.0 \%)$ were positive for Campylobacter jejuni on Karmali agar, Columbia agar base and modified Preston, respectively. These findings are in agreement with those reported by Lovett et al. (1983) and Franco (1988), slightly higher than the results obtained by Hudson et al. (1999). El-Nokrashy et al. (1997) could isolate Campylobacter jejuni from raw milk samples with higher percentages. While Mouffok and Lebres (1992) and Federighi et al. (1999) could not isolate Campylobacter jejuni from raw milk.

Serological identification of isolated Campylobacter are listed in Table 2 which show that the one Campylobacter jejuni strain recorded on Karmali agar medium belonged to Campylobacter jejuni serotype 2 and one Campylobacter jejuni isolate obtained on Columbia agar base was assigned as Campylobacter jejuni serotype 2. Modified Preston agar medium recovered 2 Campylobacter jejuni strains, which serologically assigned as Campylobacter jejuni serotype 2 and Campylobacter jejuni serotype 1.

Similar findings were reported by El-Nokrashy et al. (1997). Penner and Heniessy (1980) mentioned that most of the tested Campylobacter jejuni isolates were serologically identified as Campylobacter jejuni serotype 1 and Campylobacter jejuni serotype 2 while Fitzgerald et al. (2001) serotyped 9 Campylobacter jejuni strains using Somatic $\mathrm{O}$ typing and found that all isolates were $\mathrm{Cj} 19$.

Table 3 summarizes the antibiotic sensitivity of isolated Campylobacter jejuni from examined raw bulk milk samples. All the tested isolates $(10 \%)$ were sensitive to Gentamycin $10 \mathrm{ugm}$, Tetracycline 10 ugm, Clindamycin 2 ugm, while non of the isolates were sensitive to Cefoperazorie $30 \mathrm{ugm}$, Ampicillin $10 \mathrm{ugm}$. Out of the tested isolates $14.29 \%$ were sensitive to erythromycin $10 \mathrm{ugm}$. These results are in agreement with those reported by Wells et al. (1987) while nearly similar findings were reported by Karmali et al. (1981) and Palmgren et al. (1997). It has been receded that Campylobacter jejuni survive better in food at refrigeration temperature than at room temperature. The pathogen may remain viable in sterile milk at $4^{\circ} \mathrm{C}$ for up to 22 days, whereas at $25^{\circ} \mathrm{C}$ no viable organism could be detected after 3 days (Blaser et al., 1980; Rollins and Colwell, 1986 and Curtis et al., 1995).

Sufficient pasteurization at $62.8^{\circ} \mathrm{C}$ for 30 minutes inactivate the pathogens even when milk contains large numbers of the bacterium (Aoust et al., 1988).
Prevalence of Yersinia enterocolitica in farm bulk milk samples presented in Table 4 revealed that of 100 tested farm bulk milk samples 7 (7\%) were found to be contaminated with Yersinia enterocplitica when cultured on Bile-oxalate-sorbose (BOS) compared with $6(6 \%)$ when cultured on Yersinia enrichment broth (YEB). The results given in Table 4 show that out of 100 raw milk samples tested $5(5 \%)$ and $4(4 \%)$ were positive for Yersinia kristensenii using BOS and YEB, respectively. These findings are in agreement with those obtained by Saad and Moustafa (1989); Ali (1990) and Cotton and White (1991). Slightly higher incidences were recorded by Schiemann and Toma (1978) and Franzin et al. (1984).

Prevalence of Pseudomonas spp. in examined raw bulk samples are listed in Table 5, which shows that $50 / 100(50 \%)$ of tested samples contained Pseudomonas spp. Nearly similar incidences were reported by Katona (1981) and Ahmed (1995) while Otte et al. (1978) and Kalogridou Vasiliadou and Manalkidis (1984) recorded slightly lower values.

The high level of Pseudomonas contamination was $0.5 \times 10^{6}$; the low level was $2.3 \times 10$ and the mean value was $1.8 \times 10^{4} \pm 0.54 \times 10^{4}$. These findings are in agreement with that reported by Ahmed (1995) while lower levels were reported by Bruzynska et al. (1974). Desmasures, and GueGnen (1997) examined 34 refrigerated milk samples and found that pseudomonas count was $5.8 \times 10^{2}$.

Out of 60 Pseudomonas spp., Pseudomonas fluorescens was found to be comprise up to $50 \%$ of the total isolates. Pseudomonas maltophilia, Pseudomonas aeruginosa, Pseudomonas pickiti and Pseudomonas cepacia were comprising 16.6\%, $16.6 \%, 10.8 \%$ and $14.1 \%$ respectively (Table 6). These findings are in agreement with that reported by Ahmed (1995) while, Juffs (1973) \& Rashed and Buddary (1981) could report higher values. Lower incidences were declared by Uraz and Citak (1998).

The results given in Table 8 revealed, that out of 100 examined raw farm bulk milk samples, only $2(2 \%)$ contained E. coli O157:H7. These finding are in agreement with those reported by Wells et al. (1987) while lower incidence was reported by Steele et al. (1997), while Gooding and Choudary (1997) and Palmgren et al. (1997) could not detect E. coli O157:H7 in any of examined raw milk samples. It was reported that most of hemorrhagic colitis outbreaks resulted form consumption of under cooked minced beef or raw milk and dairy cattle have been identified as a reservoir of $\mathrm{E}$. coli O157:H7 (Blanco et al., 1996). 


\section{REFERENCES}

Ahmed, A.K.S. (1995): Assesment of pseudomonas in farm bulk milk. Ph.D Thesis, Faculty of Vet. Med., Zagazig Univ., Egypt.

Ali, M.E.A. (1990): Occurrence and behavior of pathogenic microorganisms especially Listeria monocytogens in milk and some dairy products. Ph.D Thesis, Faculty of Vet. Med., Zagazig Univ., Egypt.

Allos, B.M.; Lippy, F.T.; Carlsen, A.; Washburn, R.G. and Blaser, M.J. (1998): Campylobacter jejui strains from patients with Guillain-Barre syndrome. Emerging food-borne Diseases. 4 (2).

Anonymous (1977): Yersinia enterocolitica outbreaks. New York Morbid Mortal. Weekly Rep., 25:7.

Blanco, J.E.; Blanco, M.; Mora, M.; Prado, C.; Rio, M.; Fernandez, L.; Fernandez, M.J.; Sainz, V. and Blanco, J. (1996): Detection of Enterohaemorrhagic Escherichia coli $\mathrm{O} 157: \mathrm{H} 7$ in minced beef using immunomagnetic separation. Microbiologia, 12 (3): 985-394.

Blaser, M.J.; Hardestry, H.I.; Powers, B. and Wang, W.I.I. (1980): Survival of Campylobacter fetus subsp. Jejuni in biological milieus. J. Clinical Microbiology. 11: 309.

Bruzynska, H.; Meciejska, K.; Borowiak, M.; Czarnowska, W.; Dziurowiez, Z.; Gorecka, J.; Maciaszek, A.; Smykal, B. and Wilcz-ynskaStelmach, W. (1974): Preliminary detection of Pseudomonas aeruginosa in food. RocznikiPanstwowego- Zakladu- Higieny, 25 (6): 641-647.

Bryan, F.I. (1983): Epidemiology of milk - borne diseases. J. Food Protection, 46: 637-649.

Cotton, L.N. and White, C.H. (1991): Listeria monocytogens, Yersinia enterocolitica and Salmonella in dairy plant environment. J. Dairy Science. 75: 51-57.

Curtis, L.M.; Patrick, M. and Blackburn, C.W. (1995): Survival of Campylobacter jejuni in foods and comparison with a predictive model. Letters in Applied Microbiology. 21: 194-197.

D'Aoust, J.Y.; Park, C.E.; Szubo, R.A.; Todd, E.C.D.; Emmons, D.B. and Makellar, R.C. (1988): Thermal inactivation of Campylobacter species, Yersinia enterocolitica and Hemorrhagic coli O157:H7 in fluid milk. J. Dairy Sci., 71: 3230-3236.

Desmasures, N. and GueGnen, M. (1997): Monitoring the microbiology of high quality milk by monthly sampling over two years. J. Dairy Research. 64: 271-280.

Doyle, M.P. (1992): A new generation of food- born pathogens. Dairy, Food and Environmental Sanitation, 12 (18): 490-493.

Eley, A. (1996): Microbial food poisoning, $2^{\text {nd }}$ Edition, Chapman and Hall, London.
El-Nokrashy, S.; El-Magduib, N. and El-Dairouty, R.K. (1997): Isolation, characterization and thermal inactivation spp. from Egyptian Raw Milk. Egyp. J. Microbiol., 32 (1): 117-127.

FDA (1998): Food and drug administration. Bacteriological Analytical Manual, $8^{\text {th }}$ Edition, AOAC International, Gaithersburg, USA.

Federighi, M.; Magras, C.; Pilet, M.F.; Woodward, D.; Jihnson, W.; Jugiau, F. and Jouve, J.I. (1999): Incidence of thermo-tolerant Campylobacter in foods assessed by NFISO 10272 standard: result of a two year study. Food Microbiology 16: 195-204.

Fitzgerald, C.; Helsel, L.O.; Nicholson, M.A.; Olsen, S.J.; Swerdlow, D.L.; Flahart, R.; Sexton, J. and Fields, P.I. (2001): Evaluation of methods for subtyping Campylobacter jejuni during an outbreak involving a food handler. J. Clinical Microbiol., July, 2386-2390.

Franco, D.A. (1988): Campylobacter species: considerations for controlling a food borne pathogen. J. Food Prot., 51 (2): 145-153.

Franzin, I.; Frantino, P. and Vidotto, V. (1984): Isolation of Yersinia enterocolitica and Yersinia enterocolitica-like organisms from raw milk in Italy. Current Microbiol., 10: 357-360.

Gooding, C.M. and Choudary, P.V. (1997): Rapid and sensitive immunomagnetic separationpolymerase chain reaction method for the detection of Escherichia coli O 157: H7 in raw milk and ice cream. J. Dairy Res., 84: 87-93.

Hudson, J.A.; Nicol, C.; Wright, J.; White, R. and Hasell, S.K. (1999): Seasonal variation of Campylobacter types from human Cases, veterinary cases, raw chicken, Milk and water. J. of Applied Microbiol., 87: 115-124.

Juffs, H.S. (1973): Identification of Pseudomonas spp. isolated from milk produced in South Eastern Queensland. J. Applied Bacteriol., 36: 585-598.

Kalogridou-Vasiliadou, D. and Manalkidis, K.S. (1984): Gram- negative bacteria in Cow's raw milk. Deltio- Ethnikes- Epiropes- GalaktosEllados, 1(1): 61-73.

Karmali, M.A.; De Grandis, S. and Fleming, $P$. (1981): Antimicrobial susceptibility of Campylobacter jejuni with special reference to resistance patterns of Canadian isolates. Antimicrobial Agents and Chemotherapy. 19 (4): 593-597.

Katona, F. (1981): Hygienic aspects of the presence of Pseudomonas aeruginosa in cooled raw milk. In psychrotrophic microorganisms in spoilage and pathogenicity. Eds. Roberts, T.A; Hobbs, G, Christian, J.H.B. and Skovgoad, N., Academic Press. London.

Lovett, J.; Francis, D.W. and Hunt, J.M. (1983): Isolation of Campylobacter jejuni from raw milk. Applied and Enivronmental Microbiology. 46: 459-462. 
Morris, G.K. and Patton, C.M. (1985): Manual of clinical microbiology: Campylobacter, $4^{\text {th }}$ Edition American Society for Microbiol., Washington, DC.

Mouffok, F. and Lebres, E. (1992): Results of technique of isolation and identification of campylobacter in food. Arch. Inst. Pasteur Algerie, 58: 239-246.

Otte, I.; Hahn, G. and Tolle, A. (1978): Detection, incidence and significance of Pseudomonas aeruginosa in raw milk and in the environment of dairy cows. International Dairy Congress; E, 93-94.

Palmgren, H.; Sellin, M.; Bergstrom, S. and Olsen, B. (1997): Enteropathogenic bacteria in migrating birds arriving in Sweden. Scand. J. Infec. Dic., 29: 565-568.

Penner, J.I. and Heniessy, J.N. (1980): Passive hemagglutination technique for serotyping Campylobacter fetus subsp. Jejuni on the basis of heat- stable antigen. J. Clinical Microbiol., 12: 732-737.

Peters, J.E.; Park, SJ.; Darzins and Galloway. D.R. (2006): Molecular microbiology v6: $1155-$ 1162.

Rashed, A.M. and Buddary, F. (1981): Identification of psychrotrophs isolated from cold stored raw milk and investigation of their metabolic activity. Tejipar, 30 (3): 54-47.

Rollins, D.M. and Colwell, R.R. (1986): Viable but non- culturable stage of Campylobacter jejuni and its role in survival in the aquatic environment. Applied and Environmental Microbiol. 52: 531-538.

Saad, N.M. and Moustafa, S. (1989): Prevalence of Yersinia enterocolitica in raw milk in Assiut City. Assiut Vet. Med. J. 22 (43): 95-99.
Schiemann, D.A. and Toma, S. (1978): Isolation of Yesrsinia enterocolitica from raw milk. Applied and Environmental Microbiology. Jan P. 54-58.

Skirrow, M.B.C. (1977): Campylobacter enteritis: a "new" disease Brit. Med. J., 2: 9-11.

Steele, M.L.; Mcnab, W.B.; Poppe, C.; Griffiths, M.W. and Chen, S. (1997): Survey on Ontario bulk tank raw milk for food borne pathogens. J. Food Prot. 60 (11): P 1341-1346.

Tacket, C.O.; Narain, J.P.; Satin, R.; Lofgren, J.P.; Konigsberg, C.; Rendtorff, R.C.; Rausa, A.; Davis, B.R. and Cohen, M.L. (1984): A Multistate outbreaks of infection caused by Yersinia enterocolitica transmitted by pasteurized milk. J. Amer. Public Health Association, 251:483.

Thistad, S.L. and Danielsson-T (2005): Identification and characterization of pathogenic Yersinis enter-Colitica isolates. Apple. Envirom. Microbiol. Vol 71 No 7:3 674-3681.

Uraz, G. and Citak, S. (1998): The isolation of Pseudomonas and other Gram- negative bacteria in raw milks. J. Basic Microbiol., 38 (2): 129-134.

Wells, J.G.; Shipman, L.D.; Greene, K.D.; Downes, F.P.; Martin, M.L.; Tauxe, R.V. and Wachsmuth, L.K. (1987): Isolation of Escherichia coli O157: H7 and other shigalike/verotoxin producing $E$. coli from dairy Cattle. Int. Symp. and workshop on verocytotoxin producing infections. Abst. $\mathrm{LFE}-4$.

Wray, C. and Sojka, W.J. (1977): Reviews of the progress of dairy science: Bovine Salmoenellosis. J. Dairy Res., 44: 383-425.
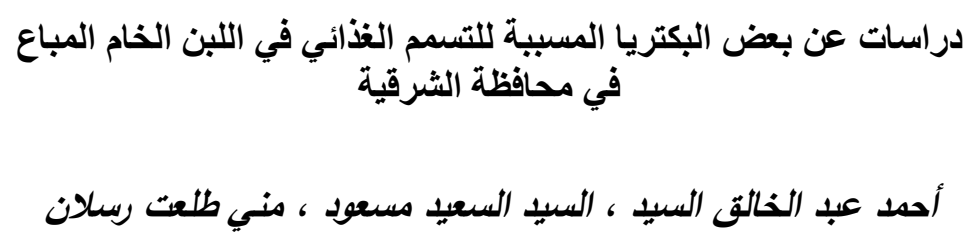

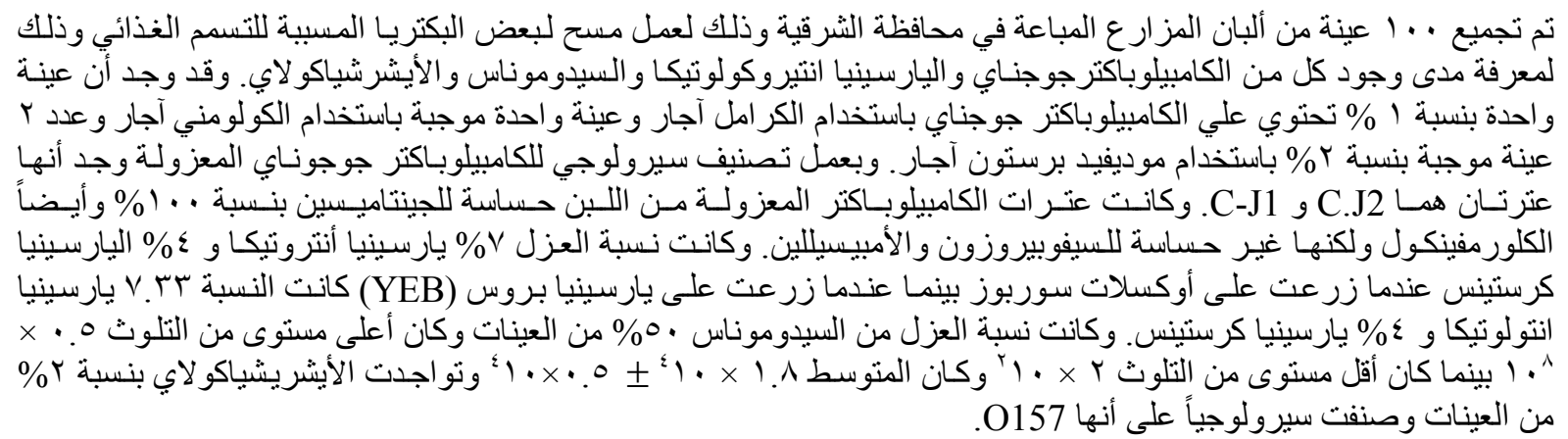

